\title{
Using Soap Waste from Biodiesel Production to Intensify Biogas Generation during Anaerobic Digestion of Cow Dung
}

\author{
${ }^{1}$ Polishchuk V.M., ${ }^{1}$ Shvorov S.A., ${ }^{2}$ Krusir G.V., ${ }^{3}$ Didur V.V., ${ }^{4}$ Witaszek K., \\ ${ }^{1}$ Pasichnyk N.A., ${ }^{1}$ Dvornyk Ye.O., ${ }^{1}$ Davidenko T.S. \\ ${ }^{1}$ National University of Life and Environmental Sciences of Ukraine, Kyiv, Ukraine \\ ${ }^{2}$ Odessa National Academy of Food Technologies, Odessa, Ukraine \\ ${ }^{3}$ Uman National University of Horticulture, Uman, Ukraine \\ ${ }^{4}$ Poznań University of Life Sciences, Poznań, Poland
}

\begin{abstract}
The aim of the work is to increase the yield of biogas and the generation of electricity at biogas plants due to the joint fermentation of cattle manure with the addition of soap stock obtained from soap waste from biodiesel production. To achieve this goal, the following tasks were solved: the yield of biogas from cattle manure was determined with the addition of soap stock for a periodic mode of loading the substrate, taking into account the data obtained, a mathematical model of biogas output for a quasi-continuous mode of loading the substrate into the digester was developed and its adequacy was confirmed. The novelty of the work lies in the fact that according to the data of experimental studies of biogas yield at a periodic loading mode using this model, it is possible to predict the maximum biogas yield for a quasi-continuous mode of loading the digester. The significance of the research results lies in the fact that when soap stock is added to the substrate with a periodic mode of loading the digester, a general increase in the biogas yield without diauxy is observed by about 2 times. The optimal content of soap stock in the substrate for a quasi-continuous mode of loading the digester, at which the biogas yield will be maximum, is $1.32 \%$. When electricity is sold at a feed-in tariff, the payback period of a biogas plant is reduced from 8.7 years to 5.0 years.
\end{abstract}

Keywords: biogas, substrate, cattle manure, soap stock, dry matter, digester, biogas plant, methane fermentation.

DOI: https://doi.org/10.52254/1857-0070.2022.1-53.08

UDC: 662.763 .3 .2

Utilizarea deșeurilor de săpun provenite din producția de biodiesel pentru intensificarea generării de biogaz

Polisciuk V.N., ${ }^{1}$ Şvorov S.A., ${ }^{2}$ Crusir G.V., ${ }^{3}$ Didur V.V., ${ }^{4}$ Vitaşec K., ${ }^{1}$ Pasicinik N.A., ${ }^{1}$ Dvornik E.A., ${ }^{1}$ Davidenko T.S.

${ }^{1}$ Universitatea Naţională a resurselor biologice și managementului bioresurselor a Ucrainei, Kyev, Ucraina

${ }^{2}$ Academia Naţională de tehnologiilor alimentare din Odesa, Odesa, Ucraina

${ }^{3}$ Universitatea Naţională de Pomicultură din Umani, Umani, Ucraina

${ }^{4}$ Universiztatea de ştiinţe naturii din Poznan, Polonia

Rezumat. Scopul lucrării este de a crește producției de biogaz și de energie electrică în instalațiile de biogaz prin fermentarea comună a gunoiului de grajd cu adaos de săpun derivat din deșeurile de săpun provenite din producția de biodiesel. Pentru a atinge acest obiectiv, au fost rezolvate următoarele sarcini: a fost determinată producerea de biogaz din gunoiul de grajd de bovine cu adaos de săpun pentru un regim periodic de încărcare cu substrat; cu considerarea datelor obținute a fost elaborat modelul matematic al producerii de biogaz pentru un regim cvasi-continuu de încărcare a substratului în fermentator şi a fost confirmată adecvarea acestuia. Noutatea lucrării constă în faptul că, în conformitate cu cercetările experimentale la producerea biogazului la modul de încărcare periodică, prin utilizarea acestui model se asigură o predicție a producerii în cantități maxime de biogaz pentru modul cvasi-continuu de încărcare a fermentatorului. Fermentarea metanică a substratului a fost realizată într-o instalație de biogaz de laborator cu un volum efectiv de 301 la temperatrura de $40^{\circ} \mathrm{C}$ prin adăugarea a $1,7 \mathrm{~kg}$ de gunoi de grajd de bovine și $2,5 \mathrm{~kg}$ de apă a unei pietre de săpun cu un volum de $0,25,50$ și $100 \mathrm{ml}$, sau $0 \%, 0,6 \%, 1,2 \%$ și 2,4\% din masa substratului. Semnificația rezultatelor cercetării constă în faptul, că la adăugarea de săpunuri la substrat într-un regim de încărcare periodică a fermentatorului se atestă o creștere generală a producerii de biogaz de aproximativ 2 ori fără prezența diauxiei. Fermentarea maximă a gunoiului de grajd de bovine cu un adaos de $0,6 \%$ de săpun este de 1,144 1/(Hg DAS), 1,2\% de săpun - 1,885 1/(Hg DAS), 2,4\% de săpun - 1,3 1/(Hg DAS).

Cuvinte-cheie: biogaz, substrat, gunoi de grajd, deșeuri de săpun, materie uscată, fermentator, instalație de biogaz, fermentare a metanului. 


\section{Использование мыльных отходов производства биодизеля для интенсификации генерирования} биогаза при анаэробном сбраживании коровьего навоза

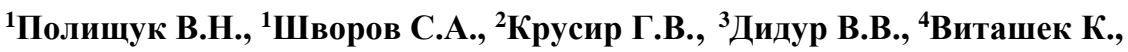

${ }^{1}$ Пасичник Н.А., ${ }^{1}$ Дворник Е.А., ${ }^{1}$ Давиденко Т.С.

${ }^{1}$ Национальный университет биоресурсов и природопользования Украины, Киев, Украина

${ }^{2}$ Одесская национальная академия пищевых технологий, Одесса, Украина

${ }^{3}$ Уманский национальный университет садоводства, Украина

${ }^{4}$ Университет естественных наук в Познани, Польша

Аннотация. Целью работы является повышение выхода биогаза и выработки электроэнергии на биогазовых установках за счет совместного сбраживания навоза крупного рогатого скота с добавлением соапстока, полученного из мыльных отходов производства биодизеля. Для достижения поставленной цели решались следующие задачи: определялся выход биогаза из навоза крупного рогатого скота с добавлением соапстока для периодического режима загрузки субстрата; с учетом полученных данных разрабатывалась математическая модель выхода биогаза для квазинепрерывного режима загрузки субстрата в метантенк и подтверждалась ее адекватность. Новизна работы заключается в том, что по данным экспериментальных исследований выхода биогаза при периодическом режиме загрузки с использованием данной модели обеспечивается прогнозирование максимального выхода биогаза для квазинепрерывного режима загрузки метантенка. На лабораторной биогазовой установке полезным объемом 30 л при температуре $40^{\circ} \mathrm{C}$ осуществлялось метановое сбраживание субстрата с добавлением к 1,7 кг коровьего навоза и 2,5 кг воды соапстока объемом 0, 25, 50 и 100 мл, или 0\%, 0,6\%, 1,2\% и 2,4\% от массы субстрата. Значимость результатов исследований состоит в том, что при добавлении соапстока к субстрату при периодическом режиме загрузки метантенка наблюдается общее увеличение выхода биогаза без наличия диауксии примерно в 2 раза. Максимальный выход биогаза при сбраживании навоза крупного рогатого скота с добавлением $0,6 \%$ соапстока составляет 1,144 л/(час·кг СОВ), 1,2\% соапстока - 1,885 л/(час·кг СОВ), 2,4\% соапстока - 1,3 л/(час·кг СОВ). Оптимальное содержание соапстока в субстрате для квазинепрерывного режима загрузки метантенка, при котором выход биогаза будет максимальным (1,91 л/(час·кг СОВ)), составляет 1,32\%. Реализация такой рецептуры субстрата позволяет сократить срок окупаемости биогазовой установки с 8,7 лет до 5,0 лет при продаже электроэнергии, произведенной при сжигании полученного биогаза по "зеленому" тарифу.

Ключевые слова: биогаз, субстрат, навоз крупного рогатого скота, соапсток, сухое вещество, метантенк, биогазовая установка, метановое брожение.

\section{ВВЕДЕНИЕ}

Основным субстратом, используемым для производсва биогаза, являются отходы: навоз сельскохозяйственных животных. Однако выход биогаза из этого субстрата относительно невелик. Поэтому значительной проблемой биогазовых установок, работающих на навозе сельскохозяйственных животных, является малый выход биогаза, что существенно снижает уровень рентабельности. Чтобы увеличить производительность биогазовых установок, к навозу добавляют косубстраты - субстраты, имеющие значительный выход биогаза. К таким косубстратам относятся отходы масличных производств и производства биодизеля.

\section{І. ПОСТАНОВКА ЗАДАЧИ}

В Украине в сезон 2020/2021 гг., по сообщению прессы, производство растительных масел составило 6,13 млн. т, из которой 5,61 млн. т идет на экспорт. В 2021/2022 гг. ожидается рекордный урожай семян подсолнечника. По разным оценкам прогнозируется от 16 до 17 млн. т. Предполагается произвести свыше 7,1-7,2 млн. т подсолнечного масла, что на 24,1\% больше прошлогоднего, из которых 6,55-6,6 млн. т будет поставлено на экспорт.

Перед экспортом и продажей на внутреннем рынке растительное масло подвергается рафинированию, в результате чего получаются такие отходы, как фуз и соапсток, которые могут использоваться в качестве косубстрата для повышения выхода биогаза. Выход соапстока при рафинировании растительных масел определяется как произведение коэффициента, который в зависимости от технологической схемы рафинирования находится в пределах 0,6-0,75, на кислотное число растительного масла. При среднем кислотном числе подсолнечного масла 3,5 мг КОН выход соапстока может составлять от 2,1\% до 2,6\%, или 149-187 тыс. т в год. Такое количество соапстока позволяет использовать его в промышленных масштабах в биогазовых установках в качестве косубстрата. 


\section{II. АНАЛИЗ ПОСЛЕДНИХ ИССЛЕДОВАНИЙ}

Соапсток - это продукт взаимодействия свободных жирных кислот, глицеридов и других мыльных примесей со щелочными растворами. Он обладает сложным и непостоянным составом, зависит от природы жира и его свойств, а также метода рафинирования и точности осуществления технологического процесса. Соапсток содержит водный раствор мыла, жиры, соединения фосфора, глицерин, красящие вещества, минеральные и механические примеси. В соапстоке может содержаться до $40 \%$ жирных кислот, нейтральных включений до $50 \%$ [1].

В работе [2] доказано, что соапсток более чем на $99 \%$ VS - это очень концентрированный субстрат для производства биогаза, выход биометана из которого составляет от 660 до 760 л/кг VS. В работе [3] проведено исследование эффективности совместного сбраживания осадка сточных вод с соапстоком. Исследования в течение 28 суток проводили в стеклянных колбах емкостью $500 \mathrm{~cm}^{3}$, оснащенных устройствами для сбора биогаза. К осадку сточных вод додавали $5 \%, 10 \%$, $15 \%, 20 \%$ и $25 \%$ соапстока. Получено увеличение производства биогаза и доли содержания метана в биогазе. Наибольший выход биогаза был зафиксирован для образцов с содержанием соапстока $5 \%$ и $10 \%$. Производство биогаза выросло на $51 \%$ и $50,5 \%$ по сравнению с контрольным образцом (без соапстока). Наивысшее содержание метана в биогазе $(74 \%)$ наблюдалось также для образцов с $\quad 5 \%$ и $10 \%$ соапстока. Добавление соапстока более $10 \%$ к осадку сточных приводило к ингибированию производства биогаза. В работе [4] утверждается, что общее сбраживание $68 \%$ сточных вод, $16 \%$ соапстока и $16 \%$ органического вещества, полученного после очистки сырого глицерина, проведенное при скорости органической нагрузки 1,5 кг $\mathrm{VS} / \mathrm{m}^{3}$ в сутки, обеспечило средний выход биометана 515 л/кг VS и уменьшение летучих твердых веществ почти на 95\%. В работе [5] сказано, что совместное сбраживание силосованных рыбных отходов и соапстока, полученного в процессе производства рыбьего жира, позволяет получить максимальный выход биогаза 775 мл/г VS в сутки. В работе [6] заявлено, что сточные воды от переработки молока, обладающие достаточно высоким содержанием липидов, перед анаэробным сбраживанием перерабатывают на флотационной установке. В результате образуются полужесткие жировые отходы, которые называются DAF float. Однако отходы с высоким содержанием липидов имеют тенденцию образовывать в реакторе нерастворимый слой налета, ограничивающий биологическое разложение отходов. Предварительная обработка омылением является возможным решением для увеличения растворимости слоя налета. Использование гидроксида натрия в качестве реагента приводило к образованию твердого нерастворимого мыла, тогда как использование гидроксида калия приводило к образованию более мягкого мыла. Поэтому их комбинацию использовали для производства однородного мыла. Результаты показали, что предварительная обработка омылением значительно повысила растворимость липидного налета.

При производстве биодизеля и очистке его путем нейтрализации с последующей промывкой водой может быть образован соапсток и его смесь с водой, которая называется сточными водами производства биодизеля $[7,8]$. На каждые 100 л биодизеля образуется от 20 л [9] до 120 л [10] промывной воды, которая представляет собой вязкую непрозрачную белую жидкость, похожую на водный раствор мыла. Содержит значительное количество метанола, глицерина и мыла. В воде также содержатся метиловые эфиры, связанные с мылом, $\mathrm{NaOH}$ или $\mathrm{KOH}$ из катализатора, натриевые или калийные соли и следы моно, ди- и триглицеридов, связанных с мылом [9]. Имеет щелочную реакцию ( $\mathrm{pH}$ 9). Промывочные сточные воды биодизеля имеют высокую химическую потребность в кислороде (60000-545000 мг/л) [10] и низкое содержание азота и фосфора, что делает их биологическую очистку проблематичным [11]. Поэтому одним из способов их очистки является анаэробное метановое сбраживание. Так, при сбраживании коровьего навоза с добавлением $13 \%$ сточных вод выход биогаза составляет 1,372 л/(ч. кг СОВ), тогда как при добавлении $2 \%-0,415$ л/(ч. кг СОВ) [12].

Относительно влияния на выход биогаза отдельных компонентов соапстока. Как отмечено в работе [13], мыло в составе сырого глицерина увеличивает выход 
биогаза, особенно после предварительной обработки эмульгированного мыльного сырья штаммом бактерий Staphylococcus haemolyticus [14]. Неочищенный глицерин, полученный при производстве биодизеля, является подтвержденным субстратом для анаэробного сбраживания. Как отмечено в работе [15], при мезофильных условиях добавление 4\% глицерина к навозу крупного рогатого скота увеличивало производство биогаза до 400\%. В работе [16] утверждается, что самый высокий выход биогаза (825,3 мл/г и 825,7 мл/г соответственно) наблюдался при добавлении 5\% и $10 \%$ сырого глицерина к коровьему навозу, тогда как добавление $15 \%$ сырого глицерина обеспечивало выход биогаза только 387,9 мл/г (контроль - 268,6 мл/г). В исследовании [17] заявлено, что от $3 \%$ до $8 \%$ сырого глицерина к навозу молочного скота увеличивало выход биогаза, а в работе [18] - добавление сырого глицерина на уровне $2 \%$ к стокам крахмальных производств увеличило производство биогаза по сравнению с контрольной обработкой, достигнув 1,979 л/(сутки). Вместе с тем, в работе [19] отмечено, что выход биогаза уменьшается при добавлении более 5\% сырого глицерина к свиному навозу.

Отработанное растительное масло и осадок растительного масла также могут применяться в качестве косубстрата для производства биогаза. Так, добавление отработанного растительного масла к навозу крупного рогатого скота позволяет получить выход биогаза 851 л/кг VS, тогда как добавление рыбных отходов - 718 л/кг VS, а силоса из испорченной травы - только 265 л/кг VS [20]. При добавлении к навозу крупного рогатого скота $1,3 \%$ осадка растительного масла максимальный выход биогаза составляет 2,073 л/час при температуре сбраживания $40^{\circ} \mathrm{C}$ [21]. Выход биометана при совместном сбраживании липидных отходов и свиного навоза составляет $326 \pm 46$ л/кг VS при времени гидравлического удержания (HRT) 50 суток, и $274 \pm 43$ л/кг VS при HRT 30 суток [22]. Добавление отходов растительного масла в навоз увеличивает выход биогаза на $88,3 \%$ [23] и составляет $0,65 \mathrm{~m}^{3} /$ кг $\mathrm{VS} \quad$ при содержании метана 65\% [24], а также 291,4 л/кг VS [25].

Итак, в рассматриваемых литературных источниках описано анаэробное сбраживание сточных вод производства биодизеля с содержанием соапстока и отдельных компонентов соапстока: жиров, мыла, сырого глицерина. В меньшей степени освещается анаэробное сбраживание соапстока, полученное в результате очистки растительных масел. Установлено, что добавление к навозу крупного рогатого скота и другим субстратам соапстока и сточных вод производства биодизеля, увеличивает выход биогаза. Однако систематизировать величину добавления этих косубстратов и значение выхода биогаза достаточно сложно, поскольку исследования, описанные в разных литературных источниках, проводились при разных условиях, кроме того, значения выхода биогаза приведены в разных системных единицах.

Поэтому задачей наших исследований является: уточнить выход биогаза при сбраживании навоза крупного рогатого скота с добавлением соапстока для периодического режима загрузки субстрата; разработать математическую модель выхода биогаза для квазинепрерывного режима загрузки субстрата в составе навоза крупного рогатого скота и соапстока на основе экспериментальных исследований для периодического режима загрузки и подтвердить ее адекватность.

\section{III. МЕТОДИКА ИССЛЕДОВАНИЙ}

Исследование влияния соапстока в субстрате на основе навоза крупного рогатого скота на динамику и максимальный выход биогаза проводились на лабораторной биогазовой установке в составе метантенка с периодическим режимом загрузки сырья и газгольдера "мокрого" типа (рис. 1). Контроль и регулировку температуры брожения осуществляли терморегулятором ТРЦ-02 через термометр сопротивления ТСМ-50. Объем полученного биогаза один или несколько раз в сутки определялся по шкале, закрепленной на направляющей 15, по высоте поднятия цилиндра-уравнемера 14 газгольдера, с последующим пересчетом при известном диаметре цилиндра-уравнемера, который составляет 20 см. В метантенк загружался отмеренный объем субстрата, кран 16 закрывался для создания анаэробного режима. При существенном уменьшении интенсивности выхода биогаза часть субстрата сливалась из метантенка, при этом оставалась затравочная порция субстрата, содержащего 
метанообразующие бактерии, в объеме 1/3-2/3 от объема метантенка. Температурный режим метантенка при исследовании составлял $40^{\circ} \mathrm{C}$. При экспериментальном исследовании выхода биогаза при сбраживании навоза крупного рогатого скота к субстрату, состоявшему из 1,7 кг навоза крупного рогатого скота и 2,5 кг воды, добавлялось 25,50 и 100 мл соапстока, или $0,6 \%, 1,2 \%$ и $2,4 \%$ от массы субстрата. Для

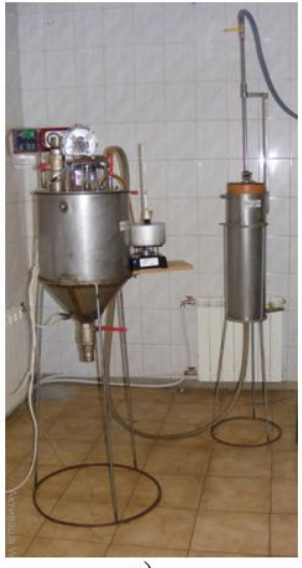

a) контроля проводились исследования без добавления соапстока. Метантенк полезным объемом 30 л загружался субстратом наполовину (коэффициент загрузки - 0,5, загруженный объем метантенка составлял 15 л). При добавлении новой порции субстрата переброженный субстрат обновлялся наполовину (коэффициент опорожнения $-0,5$ ).

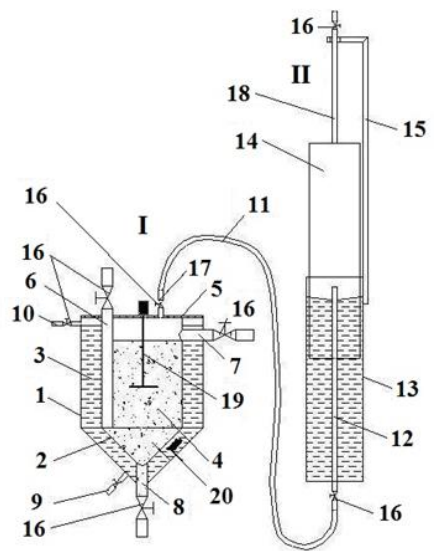

b)

$a$ - общий вид; $\sigma$ - принципиальная схема; I-метантенк; II - газгольдер; 1 - наружный корпус метантенка; 2 - внутренний корпус метантенка; 3 - водяная рубашка; 4 - активная зона метантенка; 5 - крышка; 6, 7, 8 - труба для подачи биомассы, сливания и удаления шлама; 9, 10 - труба для подачи и установки уровня воды в водяной рубашке; 11 -газопровод; 12 - трубка для подачи биогаза; 13 - корпус газгольдера; 14 - иилиндр-уровнемер; 15 направляющая; 16 - кран; 17 - трубка для отвода биогаза из активной зоны метантенка; 18 трубка для отбора газа из газгольдера; 19 -мешалка; 20 -нагреватель

Рис. 1. Лабораторная биогазовая установка. ${ }^{1}$

Критерием эффективности биогазовых технологий является величина выхода биогаза и содержание в нем метана (тепловая ценность биогаза определялась по экспрессметоду).

\section{IV. РЕЗУЛЬТАТЫ ИССЛЕДОВАНИЙ}

Результаты исследований динамики скорости выхода биогаза при сбраживании навоза крупного рогатого скота с добавлением соапстока представлены на рис. 2.

Из рис. 2 видно, что при добавлении соапстока к субстрату на основе навоза крупного рогатого скота наблюдается общее увеличение выхода биогаза примерно в 2 раза, пиковое - до 2,4 раза. Диауксия не наблюдается.

Максимальный выход биогаза при периодической системе загрузки метантенка при сбраживании навоза крупного рогатого скота с добавлением $0,6 \%$ соапстока

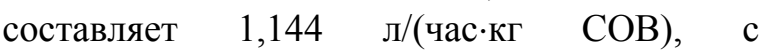

добавлением $1,2 \%$ соапстока - 1,885 л/(час·кг СОВ), с добавлением $2,4 \%$ соапстока - 1,3 л/(час·кг СОВ).

Коэффициент пересчета выхода биогаза из размерности л/(час.кГ СОВ) в размерность л/(час·кг) при добавлении $0,6 \%$ соапстока к субстрату составляет 18,943 кг/кг СОВ, 1,2\% - 19,055 кг/кг СОВ, 2,3\% - 19,279 кг/кг СОВ.

Кумулятивный выход биогаза при сбраживании навоза крупного рогатого скота с добавлением соапстока приведен на рис. 3, из которого видно, что на 15 сутки брожения накопленный выход биогаза при сбраживании навоза крупного рогатого скота с добавлением соапстока составляет: 312,7 л/кг СОВ при добавлении $0,6 \%$ соапстока от массы субстрата, 307,2 л/кг СОВ - при добавлении $1,2 \%$ соапстока от массы субстрата, 227,4 л/кг СОВ - при добавлении $2,4 \%$ соапстока от массы субстрата, 193,1 л/кг СОВ - без добавления соапстока (среднее значение). 


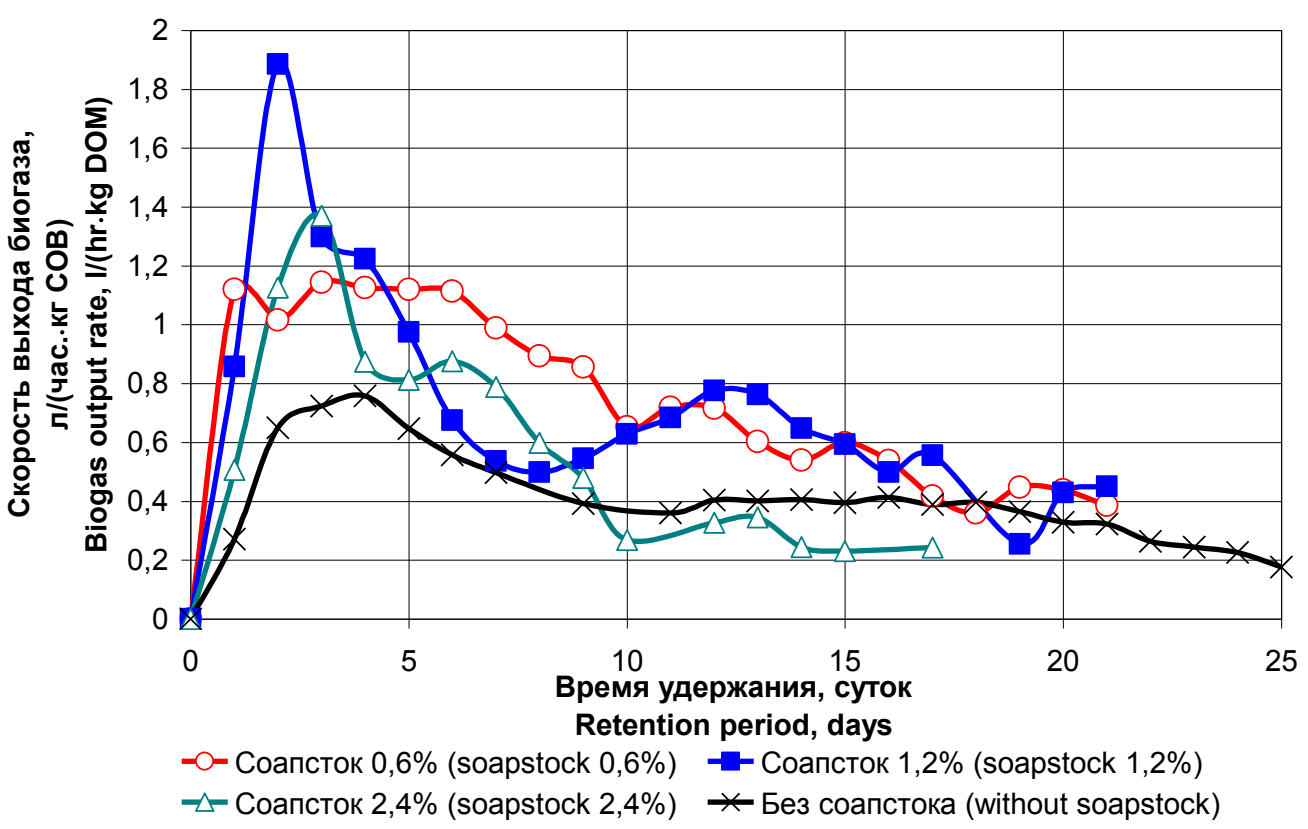

Рис. 2. Динамика скорости выхода биогаза при метановом сбраживании навоза крупного рогатого скота с добавлением соапстока при температуре броджения $40^{\circ} \mathrm{C} .^{2}$

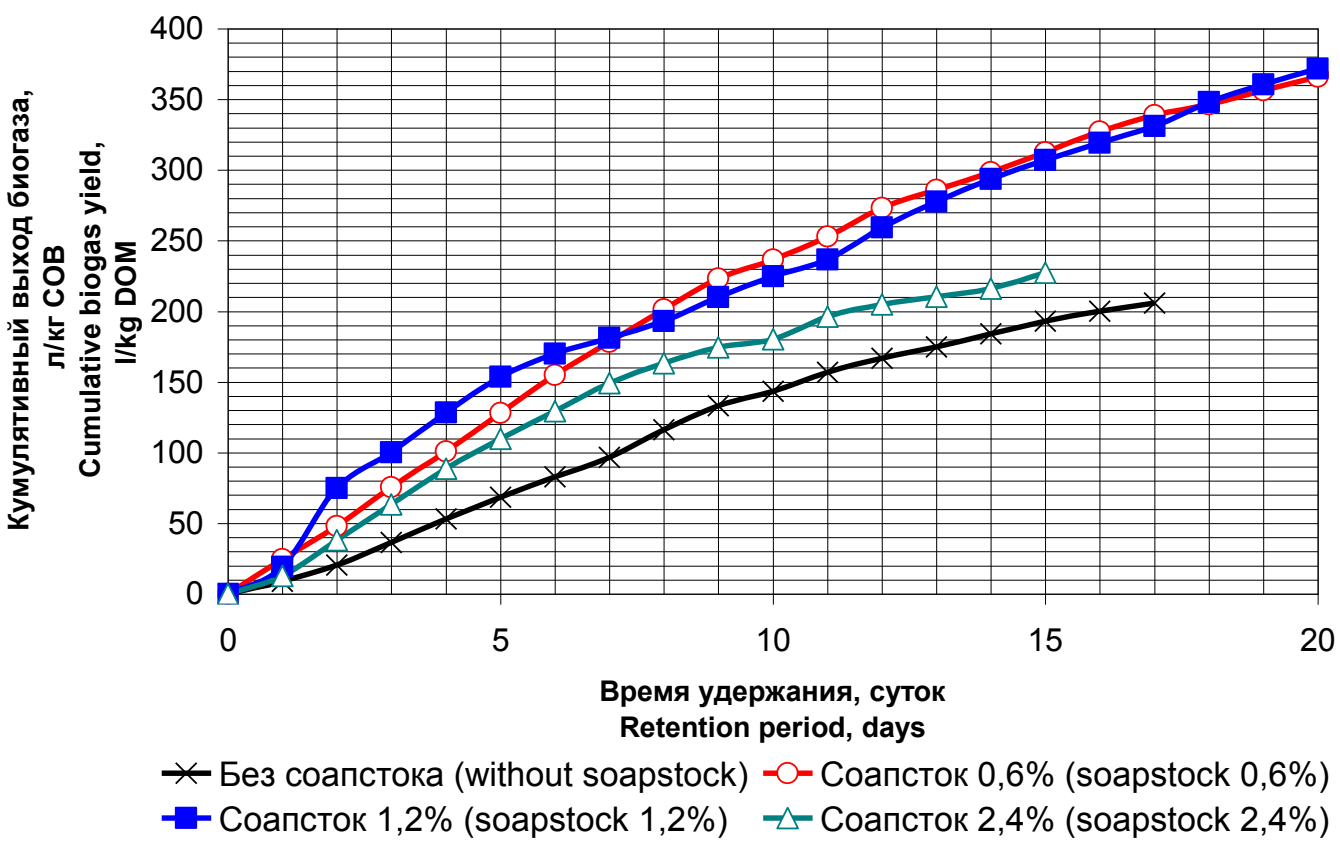

Рис. 3. Кумулятивный выход биогаза при метановом сбраживании навоза крупного рогатого скота с добавлением соапстока при температуре брожения $40^{\circ} \mathrm{C} .{ }^{3}$

Кумулятивный выход биогаза при добавлении $1,2 \%$ соапстока от массы субстрата на начальном этапе брожения (до 7 суток) несколько превышает кумулятивный выход биогаза при добавлении $0,6 \%$ соапстока от массы субстрата за счет большего пикового выхода биогаза. После 7 суток брожения кумулятивный выход биогаза при добавлении как $0,6 \%$, так и $1,2 \%$ соапстока от массы субстрата, почти одинаков и превышает кумулятивний выход биогаза из субстрата без добавления соапстока на 20 сутки почти в 1,7 раза. При добавлении $2,4 \%$ соапстока от массы субстрата щелочность субстрата уже не так благоприятна для метанообразующих бактерий, поэтому кумулятивный выход биогаза несколько уменьшается по сравнению с меньшим добавлением соапстока, хотя и больше выхода биогаза из субстрата без соапстока.

Кумулятивный выход биогаза при 
сбраживании навоза крупного рогатого скота с добавлением соапстока при температуре брожения выражением:

$40^{\circ} \mathrm{C}$

аппроксимируется

$$
\begin{gathered}
V_{\text {bacc }}=-0.1824 \cdot S o \cdot t^{2}-0.326 \cdot t^{2}+0.7333 \cdot S o \cdot t+ \\
\quad+22.38 \cdot t-13.415 \cdot S o^{2}+34.633 \cdot S o-12.859
\end{gathered}
$$

$$
\text { при } \mathrm{R}^{2}=0.8686,
$$

где $V_{b}$ acc - кумулятивный выход биогаза, л/кг $\mathrm{COB}$; So - содержание соапстока в субстрате, $\% ; t-$ время удержания, суток.

При проверке по критерию Фишера установлена значимость коэффициента детерминации. Проверка по критерию Стьюдента показала, что все коэффициенты выражения (1) значимы.

Поверхность отклика, построенная по уравнению регрессии (1), приведена на рис. 4.

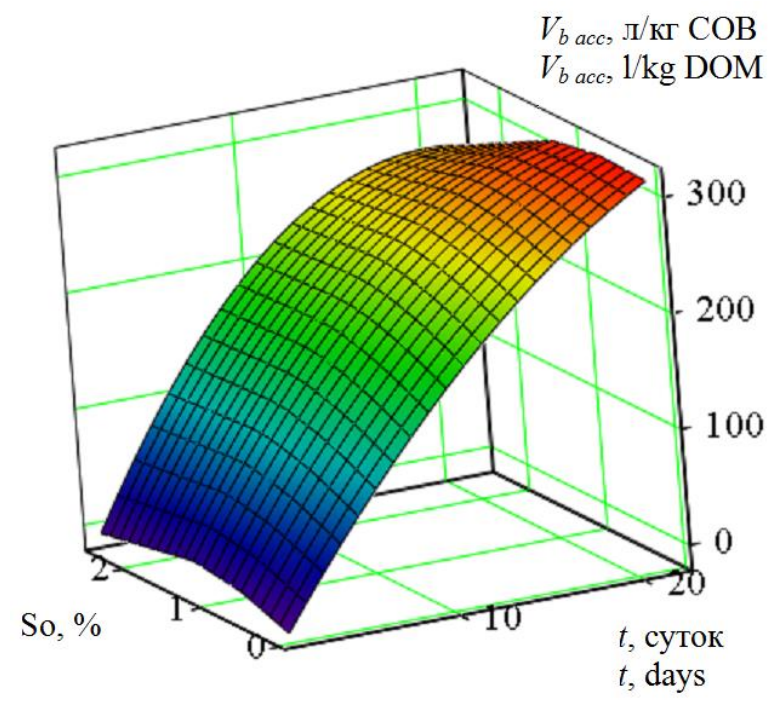

Рис. 4. Поверхность отклика, описывающая кумулятивный выход биогаза при сбраживании навоза крупного рогатого скота с добавлением соапстока при температуре брожения $40^{\circ} \mathrm{C} .{ }^{4}$

Биогаз, полученный при сбраживании навоза крупного рогатого скота с добавлением соапстока, в первые двое суток брожения не горел, после чего горение биогаза стабилизировалось. Теплота сгорания

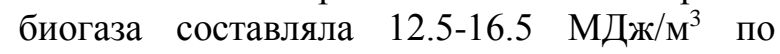
экспресс-методу.

Моделирование квазинепрерывной метантенка на выхода биогаза при системе загрузке основе результатов экспериментальных исследований выхода биогаза при периодической загрузке метантенка субстратом на основе навоза крупного рогатого скота с добавлением соапстока. Метантенк биогазовой установки, на которой проводились экспериментальные исследования, пригоден для периодической загрузки субстрата. Режим квазинепрерывной загрузки субстрата на нем выполнить достаточно сложно. Вместе с тем, на практике на действующих биогазовых установках периодический режим загрузки метантенка применяется редко, чаще используется квазинепрерывная загрузка, когда субстрат в метантенк загружается малыми порциями через определенный промежуток времени (как правило, около 1 часа). При этом выход биогаза достигает максимального, что можно достичь при периодической системе загрузки, значения и держится на таком уровне в течение всего времени работы биогазовой установки. Поэтому на основе опытов при периодической системе загрузки метантенка можно смоделировать выход биогаза при квазинепрерывной системе загрузки. На основе данных, приведенных в работе [30], а также собственных исследований, можно утверждать, что выход биогаза при квазинепрерывной системе загрузки будет близок к максимальному выходу биогаза при периодической системе загрузки субстрата.

Из рис. 2 установлено, что максимальный выход биогаза при периодической системе загрузки метантенка при сбраживании навоза крупного рогатого скота с добавлением $0,6 \%$ соапстока составляет 1,144 л/(час·кг СОВ), с 
добавлением $1,2 \%$ соапстока - 1,3 л/(час·кг $\mathrm{COB})$, с добавлением $2,4 \%$ соапстока $-1,885$ л/(час·кг СОВ). Смоделированный выход биогаза при сбраживании навоза крупного рогатого скота с добавлением соапстока для квазинепрерывной загрузки метантенка при температуре б рожения $40^{\circ} \mathrm{C}$ приведен на рис. 5.

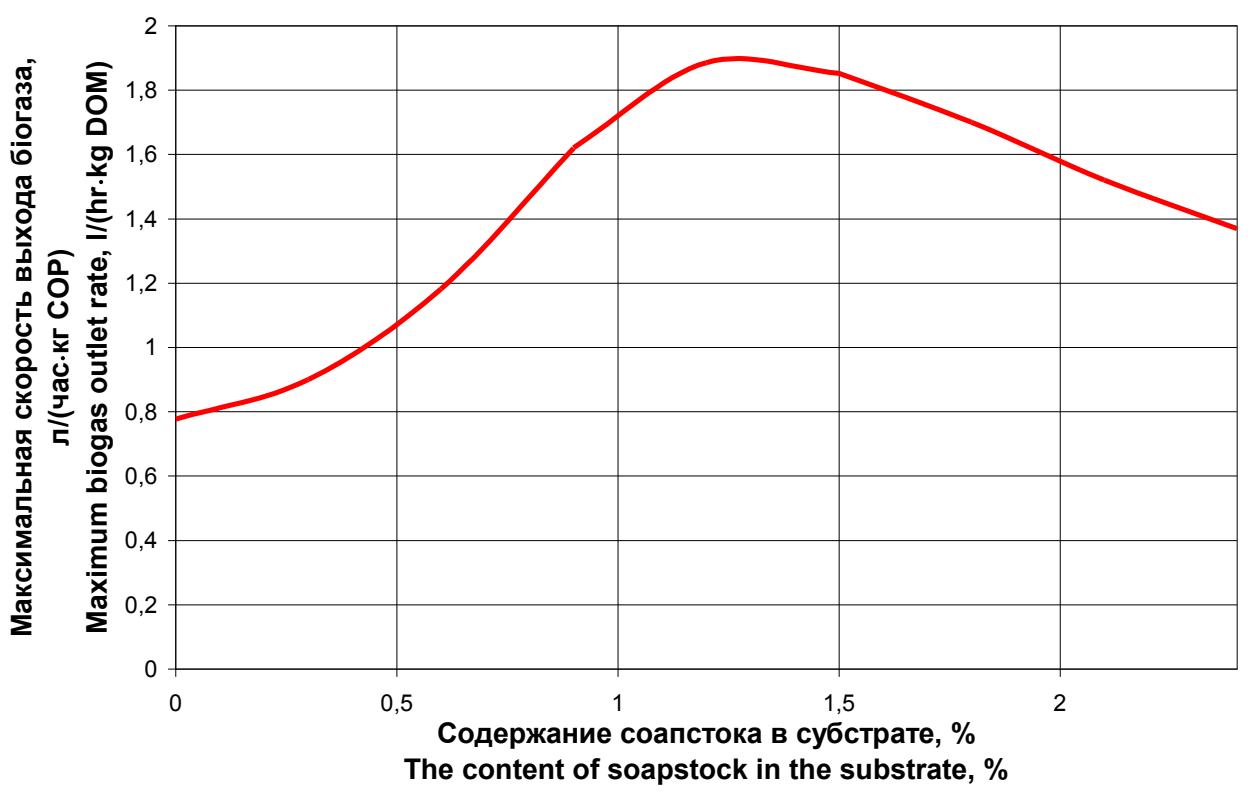

Рис. 5. Смоделированный выход биогаза при сбраживании навоза крупного рогатого скота с добавлением соапстока для квазинепрерывной загрузки метантенка. ${ }^{5}$

Аппроксимация смоделированного выхода биогаза при сбраживании навоза крупного рогатого скота с добавлением соапстока для квазинепрерывной системы загрузки метантенка при температуре брожения $40^{\circ} \mathrm{C} \mathrm{c}$ помощью полинома Ньютона дает достоверные результаты только в точках, полученных в результате эксперимента. В других точках, при прогнозировании, значения, полученные по полиному Ньютона, не соответствуют принятому тренду. Поэтому было принято решение:смоделированный выход биогаза аппроксимировать с помощью трех полиномиальных функций:

$$
\begin{gathered}
V_{b \text { mod }}=0.8722 \cdot S o^{2}+0.1517 \cdot S o+0.776 \text { для } S o \leq 0.9 \text { при } \mathrm{R}^{2}=0.9950, \\
V_{b \bmod }=-1.6556 \cdot S^{2}+4.36 \cdot S o-0.963 \text { для } 0.9 \leq S o \leq 1.5 \text { при } \mathrm{R}^{2}=0.9997, \\
V_{b \text { mod }}=0.358 \cdot S o^{3}-2.0889 \cdot S^{2}+3.4544 \cdot S o+0.162 \text { для } 1.5 \leq S o \leq 2.4 \text { при } \mathrm{R}^{2}=0.9995,
\end{gathered}
$$

где $V_{b}$ mod - смоделированный выход биогаза для квазинепрерывной системы загрузки метантенка, л/кг COB; So - содержание соапстока в субстрате, \%.

Коэффициенты аппроксимированных детерминации омоводелированный выход биогаза при сбраживании навоза крупного рогатого скота с добавлением соапстока для квазинепрерывной системы загрузки метантенка при температуре брожения $40^{\circ} \mathrm{C}$, приближается к единице, что говорит о том, что полученные уравнения регрессии достаточно точно отражают экспериментальные данные. При проверке по критерию Фишера установлена значимость коэффициентов детерминации. Проверка по критерию Стьюдента показала, что коэффициенты функций (2) значимы.

Функция $V_{b_{-} m o d}=f(S o)$ была исследована на экстремум $V_{b_{-} \bmod } \rightarrow \max$ методом дихотомии. Установлено, что оптимальное содержание соапстока в субстрате для квазинепрерывного режима загрузки метантенка, при котором выход биогаза будет максимальным, а именно 1,91 л/(час·кг COB), составляет $\mathrm{So}=1,32 \%$.

По нашим расчетам, при моносбраживании навоза из фермы на 1000 голов крупного 
рогатого скота (из них 500 дойных коров) суточный выход биогаза составит более $8, .5$ тыс. $\mathbf{M}^{3}$. При этом срок окупаемости биогазовой установки в составе двух метантенков объемом по $1800 \mathrm{~m}^{3}$ (один из которых выступает в роли дображивателя, в котором производится до $20 \%$ биогаза) при цене электроэнергии, полученной из биогаза по "зеленому" тарифу 0,145 \$/кВт.час, составляет 8,7 года. При использовании в качестве косубстрата соапстока в количестве $1,32 \%$, полученного при производстве растительных масел иди биодизеля, которые можно организовать в этом же хозяйстве, суточный выход биогаза увеличится до 24 тыс. $\mathrm{m}^{3}$, а срок окупаемости биогазовой установки по "зеленому" тарифу сократится до 5,0 лет.

\section{V. ВЫВОДЫ}

На основе проведенного исследования были получены следующие результаты:

- при добавлении соапстока к субстрату на основе навоза крупного рогатого скота при периодическом режиме загрузки метантенка наблюдается общее увеличение выхода биогаза примерно в 2 раза, пиковое - до 2,4 раза; метановое сбраживание субстрата происходит без наличия диауксии;

- максимальный выход биогаза при периодической системе загрузки метантенка при сбраживании навоза крупного рогатого скота с добавлением $0,6 \%$ соапстока составляет $\quad 1,144 \quad$ л/(час·кг $\quad$ СОР $), \quad 1,2 \%$ соапстока - 1,885 л/(час·кг СОР), $2,4 \%$ соапстока - 1,3 л/(час·кг СОР);

- оптимальное содержание соапстока в субстрате на основе навоза крупного рогатого скота для квазинепрерывного режима загрузки метантенка, при котором выход биогаза будет максимальным (1,91 л/(час·кг СОР)), составляет $1,32 \%$;

- использование соапстока в качестве косубстрата к навозу крупного рогатого скота, позволяет уменьшить срок окупаемости биогазовой установки с 8,7 лет до 5,0 лет, при продаже электроэнергии, произведенной при сжигании полученного биогаза по "зеленому" тарифу.

\section{Appendix 1}

${ }^{1}$ Fig. 1. Laboratory biogas plant: $\mathrm{a}$ - general view; $\mathrm{b}$ schematic diagram; I - digester; II - gas holder; 1 - the outer casing of the digester; 2 - inner body of the digester; 3 - water jacket; 4 - the active zone of the digester; 5 - cover; $6,7,8$ - pipe for biomass supply, drainage and sludge removal; 9, 10 - pipe for supplying and setting the water level in the water jacket; 11 - gas pipeline; 12 - tube for biogas supply; 13 - gas tank body; 14 - cylinder-level gauge; 15 guide; 16 - crane; 17 - tube for removing biogas from the digester core; 18 - tube for gas sampling from the gasholder; 19 - stirrer; 20 - heater.

${ }^{2}$ Fig. 2. Dynamics of the biogas yield rate during methane fermentation of cattle manure with addition of soapstock at a fermentation temperature of $40^{\circ} \mathrm{C}$.

${ }^{3}$ Fig. 3. Cumulative biogas yield during methane fermentation of cattle manure with addition of soapstock at a fermentation temperature of $40^{\circ} \mathrm{C}$.

${ }^{4}$ Fig. 4. Response surface describing the cumulative biogas yield during fermentation of cattle manure with the addition of soap stock at a fermentation temperature of $40^{\circ} \mathrm{C}$.

${ }^{5}$ Fig. 5. Simulated biogas yield during fermentation of cattle manure with addition of soap stock for quasicontinuous loading of the digester.

\section{Библиография (References)}

[1] Soapstock. Specifications. (2008). DSTU 5033:2008 from 4d August 2008. Kyiv: Derzhspozhyvstandart Ukraine [in Ukrainian].

[2] Ward, A.J. (2012). Biogas potential of soapstock and bleaching earth: DCA report. Aarhus Universitet, National Centre for Food and Agriculture. 19 p. ISBN 978-87-92869-11-1.

[3] Kalemba, K., Barbusinski, K. (2017). An Attempt at Co-digestion of Sewage Sludge and Soapstock - A By-product of Vegetable Oil Refining. Ochrona srodowiska. Vol. 39. no. 4. pp. 47-50.

[4] Borowski, S., Cieciura-Wloch, W. (2021). Enzymatic Pretreatment of Byproducts from Soapstock Splitting and Glycerol Processing for Improvement of Biogas Production. Molecules. Vol. 26. no. 22. Article number 6782. doi: $10.3390 /$ molecules 26226782 .

[5] Sarker, S. (2020). By-products of Fish-Oil Refinery As Potential Substrates for Biogas Production in Norway: A Preliminary Study. Results in Engineering. Vol. 6. Article number 100137. doi: 10.1016/j.rineng.2020.100137.

[6] Kurnianto, R.W., Cahyono, R.B., Budhijanto, W. (2019). Evaluation of Inoculum Source and Saponification Pre-Treatment in Anaerobic Digestion of Dissolved Air Flotation Waste from Dairy Industry. For results 11th Regional Conference on Chemical Engineering (RCChE) (Nov 07-08, 2018, Yogyakarta, Indonesia), AIP Conference Proceedings. 2085. Article number 020009. doi: 10.1063/1.5094987.

[7] Tarasenko S., Antypov Je., Kozak N., Zhyltsov A., Bereziuk A., Polishchuk V. (2020). Investigation of the Efficiency of Wet Biodiesel Purification. For results 6-th International Conference: Renewable Energy Sources (ICoRES 2019) (June 12-14, Vol. 2019, Krynica, 
Poland), E3S Web of Conferences. Vol. 154. Article number $02006 . \quad$ doi: 10.1051/e3sconf/202015402006.

[8] Tarasenko S., Antypov Je., Kozak N., Zhyltsov A., Okushko O., Polishchuk V. (2020). Study of Methods of Biodiesel Neutralization with Aqueous Solution of Lymonic Acid. For results 6-th International Conference: Renewable Energy Sources (ICoRES 2019) (June 12-14, 2019, Krynica, Poland), E3S Web of Conferences. Vol. 154. Article number 02007. doi: 10.1051/e3sconf/202015402007.

[9] Kolesarova, N., Hutnan, M., Bodik, I., Spalkova, V. (2011). Utilization of Biodiesel By-Products for Biogas Production. Journal of Biomedicine and Biotechnology. Vol. 11. Article number 126798. doi: 10.1155/2011/126798.

[10] Rattanapan, C., Sawain, A., Suksaroj, T., Suksaroj, C. (2011). Enhanced efficiency of dissolved air flotation for biodiesel wastewater treatment by acidification and coagulation processes. Desalination. Vol. 280. no. 1-3. pp. 370-377. doi: 10.1016/j.desal.2011.07.018.

[11] Phukingngam, D., Chavalparit, O., Somchai, D., Ongwandee, M. (2011). Anaerobic baffled reactor treatment of biodiesel-processing wastewater with high strength of methanol and glycerol: reactor performance and biogas production. Chemical Papers. Vol. 65. no. 5. pp. 644-651. doi: 10.2478/s11696-011-0061-y.

[12] Krusir G.V., Polishchuk V.M., Shvorov S.A., Davidenko T.S. (2020). Increase of the Biogas Output during Fermentation of Manure of Cattle with Winemaking Waste in Biogas Plants. Problemele Energeticii regionale. Vol. 2, no. 46. pp. $123 \square$ 134. doi: 10.5281/zenodo.3898326.

[13] Kurahashi, K., Kimura, C., Fujimoto, Y., Tokumoto, H. (2017). Value-adding conversion and volume reduction of sewage sludge by anaerobic co-digestion with crude glycerol. Bioresource Technology. Vol. 232. pp. 119-125. doi: 10.1016/j.biortech.2017.02.012.

[14] Cherif, S., Aloui, F., Carriere, F., Sayadi, S. (2014). Lipase Pre-Hydrolysis Enhance Anaerobic Biodigestion of Soap Stock from an Oil Refining Industry. Journal of Oleo Science. Vol. 63. no. 2. pp. 109-114. doi: 10.5650/jos.ess 13150 .

[15] Castrillon, L., Fernandez-Nava, Y., Ormaechea, P., Maranon, E. (2011). Optimization of biogas production from cattle manure by pre-treatment with ultrasound and co-digestion with crude glycerin. Bioresource Technology. Vol. 102. no. 17. pp. 7845-7849. doi: 10.1016/j.biortech.2011.05.047.

[16] Robra, S., da Cruz, R.S., de Oliveira, A.M., Neto, J.A.A. Santos, J.V. (2010). Generation of biogas using crude glycerin from biodiesel production as a supplement to cattle slurry.
Bionass \& Bioenergy. Vol. 34. no. 9. pp. 13301335. doi: 10.1016/j.biombioe.2010.04.021.

[17] Simm, S., Orrico, A.C.A., Orrico, M.A.P., Sunada, N.D., Schwingel, A.W., Costa, M.S.S.D. (2017). Crude glycerin in anaerobic co-digestion of dairy cattle manure increases methane production. Scientia Agricola. Vol. 74. no. 3. pp. 175-179. doi: 10.1590/1678-992X2016-0057.

[18] Larsen, A.C., Gomes, B.M., Gomes, S.D., Zenatti, D.C., Torres, D.G.B. (2013). Anaerobic co-digestion of crude glycerin and starch industry effluent. Ehgenharia Agricola. Vol. 33. no. 2. pp. 341-352. doi: 10.1590/S010069162013000200013.

[19] Veroneze, M.L., Schwantes, D., Goncalves, A.C., Richart, A., Manfrin, J., Schiller, A.D., Schuba, T.B. (2019). Production of biogas and biofertilizer using anaerobic reactors with swine manure and glycerin doses. Journal of Cleaner Production. Vol. 213. pp. 176-184. doi: 10.1016/j.jclepro.2018.12.181.

[20] Ervasti, S., Vainio, M., Tampio, E. (2019). Use of local resources as co-substrates in a farmscale biogas plant. Open Agriculture. Vol. 4. no. 1. pp. 650-660. doi: 10.1515/opag-2019-0065.

[21] Rogovskii I.L., Polishchuk V.M., Titova L.L., Sivak I.M., Vyhovskyi A.Yu., Drahnev S.V., Voinash S.A. (2020). Study of Biogas During Fermentation of Cattle Manure Using A Stimulating Additive In Form Of Vegetable Oil Sediment. ARPN Journal of Engineering and Applied Sciences. Vol. 15. no. 22. pp. $2652 \square 2663 /$

[22] Fierro, J., Martinez, E.J., Moran, A., Gomez, X. (2014). Valorisation of used cooking oil sludge by codigestion with swine manure. Waste Management. Vol. 34. no. 8. pp. 1537-1545. doi: 10.1016/j.wasman.2014.02.006.

[23] Alqaralleh, R.M., Kennedy, K., Delatolla, R. (2018). Improving biogas production from anaerobic co-digestion of Thickened Waste Activated Sludge (TWAS) and fat, oil and grease (FOG) using a dual-stage hyperthermophilic/thermophilic semi-continuous reactor. Journal of Environmental Management. Vol. 217. pp. 416-428. doi: 10.1016/j.jenvman.2018.03.123.

[24] Hidalgo, D., Gomez, M., Martin-Marroquin, J.M., Aguado, A., Sastre, E. (2015). Two-phase anaerobic co-digestion of used vegetable oils' wastes and pig manure. International Journal of Environmental Science and Technology. Vol. 12. no. 5. pp. 1727-1736. doi: 10.1007/s13762014-0560-9.

[25] da Silva Sunada, N., Orrico, A.C.A., Junior, M.A.P.O., Junior, J.L., Lopes, W.R.T., Schwingel, A.W. (2018). Anaerobic codigestion of animal manure at different waste cooking oil concentrations. Ciencia Rural. Vol. 
48. no. 7. Article number e20170517. doi:

Сведения об авторах.

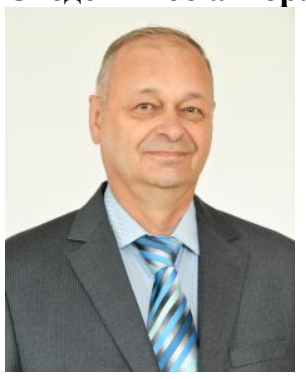

Полищук Виктор

Николаевич. Национальный университет биоресурсов и природопользования Украины, кафедра охраны труда и биотехнических систем в животноводстве, доктор технических наук, профессор. Основная область исследований: технологии и технические средства производства биотоплива.

E-mail:

polischuk.v.m@gmail.com

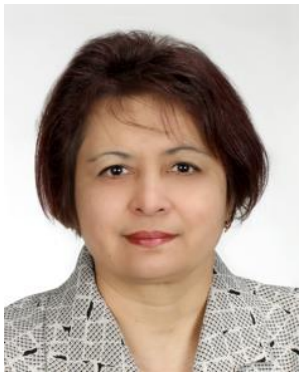

Крусир Галина Всеволодовна. Одесская национальная академия пищевых технологий, Украина, кафедра экологии и природоохранных технологий, доктор технических наук, профессор. Основная область исследований: биотехнология биологически активных добавок и защита окружающей среды. E-mail: krussir.65@gmail.com

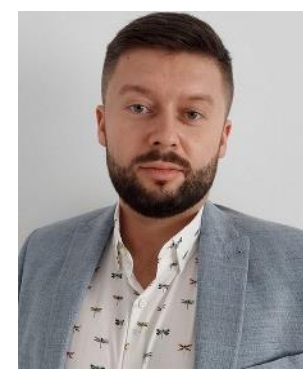

Университет естественных наук в Познани, Польша, кафедра инженерии биосистем, кандидат технических наук, доцент. Основная область исследований: прикладная фотоэлектрическая энергия, технологии производства кормов, экструзия, управление отходами, ферментация метана.

E-mail:

kamil.witaszek@up.poznan.pl

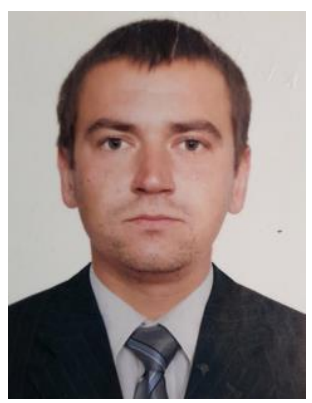

Дворник Евгений Алексеевич. Национальный университет биоресурсов у природопользования Украины, кафедра технического сервиса и инженерного менеджмента имени Н.П. Момотенка, аспирант. Основное направление исследований: технологии и технические средства производства биотоплива. E-mail: dvornykevgen@gmail.com

\section{$10.1590 / 0103-8478 \mathrm{cr} 20170517$.}

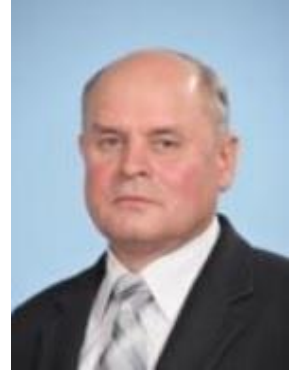

Шворов Сергей Андреевич. Национальный университет биоресурсов природопользования Украины, кафедра автоматики и робототехнических систем имени академика И.И. Мартыненка, доктор технических наук, профессор. Основная область исследований: создание робототехнических систем для сбора и переработки органического сырья.

E-mail: sosdok@i.ua

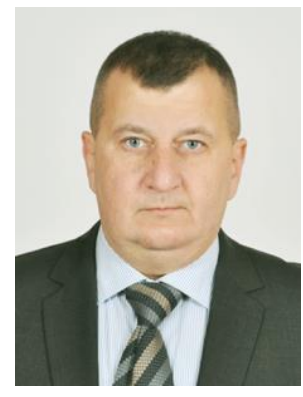

Дидур Владимир

Владимирович. Уманский национальный университет садоводства, Украина, кафедра агроинженерии, доктор технических наук, доцент. Основная область исследований: технологические процессы глубокой переработки растительного сырья масличных культур. E-mail: didur.vv@gmail.com

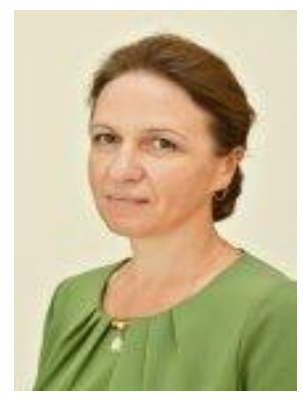

Пасичник Наталия

Анатольевна. Национальный университет биоресурсов и природопользования Украины, кафедра агрохимии и качества продукции растениеводства им. А.И. Душечкина, кандидат с.-х. наук, доцент. Основная область исследований: применение удобрений при выращивании энергетических культур.

E-mail:

n.pasichnyk@nubip.edu.ua

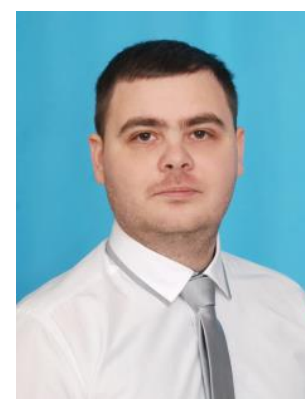

Давиденко Тарас Сергеевич. Национальный университет биоресурсов и природопользования Украины, кафедра автоматики и робототехнических систем имени академика И.И. Мартыненка, аспирант. Основная область исследований: автоматизированный контроль технологических процессов.

E-mail: davidenkotaras009@gmail.com 